\title{
Methanolic Extract of Red Betel Leaves (Piper crocatum Ruiz \& Pav) Perform Cytotoxic Effect and Antimigration Activity toward Metastatic Breast Cancer
}

\author{
Meirizky Zulharini ${ }^{1}$, Ika Rahmawati Sutejo ${ }^{3}$, Hilyatul Fadliyah ${ }^{1}$, \\ Riris Istighfari Jenie ${ }^{1,2^{*}}$ \\ ${ }^{1}$ Cancer Chemoprevention Research Center, Faculty of Pharmacy, Universitas Gadjah Mada, Indonesia \\ ${ }^{2}$ Department of Pharmaceutical Chemistry, Faculty of Pharmacy, Universitas Gadjah Mada, Indonesia \\ ${ }^{3}$ Department of Biochemistry, Faculty of Medicine, Universitas Jember, Indonesia
}

\begin{abstract}
Breast cancer is one type of cancer with a high mortality rate due to its metastatic property. Red betel leaves (Piper crocatum Ruiz dan Pav) has been known as herbal medicine containing biophenolic, such as apigenin and luteolin derivatives which has cytotoxic activity toward cancer cells. This study is intended to explore the inhibitory effect of Piper crocatum leaves methanolic extract (PCM) on cell proliferation and migration by using 4TI cells as model of metastatic breast cancer. By using MTT assay, PCM performed cytotoxic activity in a dose dependent manner with $\mathrm{IC}_{50}$ value of $120 \mu \mathrm{g} / \mathrm{mL}$. Wound healing assay revealed that migration inhibitory activity of PCM on $4 \mathrm{TI}$ cells at the concentration of $30 \mu \mathrm{g} / \mathrm{mL}$. In conclusion, PCM perform cytotoxic effect and antimigration activity toward metastatic breast cancer cells.
\end{abstract}

Keywords : breast cancer cells, Piper crocatum Ruiz \& Pav, cytotoxic, cell mgration

\section{INTRODUCTION}

Globally, breast cancer is the most common disease in women with new cases incidence of 1.38 million per year (Eccles, et al., 2013). High mortality rate of breast cancer patients usually due to the late prognosis of the disease, such as recently detected in the metastasis phase. This phase is characterized by high expression of matrix metalloproteinases (MMPs), cell migration, invasion and other phenomena associated with metastatic cascade (Leber, et al., 2009). These conditions cannot be treated only with radiation therapy or by surgery, but rather need to be developed through chemotherapy drugs. However, chemotherapy drugs often also cannot eradicate completely, such as doxorubicin that can trigger the occurrence of metastasis through induction of epithelial-mesenchymal transition (EMT) (Bandyopadhyay, et al., 2010). Therefore to overcome the metastatic cancer it is needed to develop the alternative therapeutic agents that can work more effectively.

Among the medicinal plants in Indonesia, Red Betel or Sirih Merah leaves (Piper crocatum Ruiz dan Pav) use to be consumed for healthy purposes, including to cure breast cancer (Manoi, 2007). Sirih
Merah was reported to contain biophenolics such as hydroxychavicol, eugenol, chavibetol, piperol (Gundala and Aneja, 2014). Some of these compound has been shown to exert antimutagenic (Chang, et al., 2002), antiproliferative activity in prostate cancer (Paranjpe, et al., 2013), enhance tumor growth by downregulation of NF-KB pathway (Sarkar, et al., 2008), and also eliminate cancerous cells without harming normal cells (Guha, 2006). Other study revealed that apigenin, luteolin, and flavonoid derivatives present in Sirih Merah leaves (Ferreres, et al., 2014). Meanwhile, flavonoid compounds are reported to have activity to inhibit cancer cell migration through suppressing the expression of MMP-9 and phosphorylation of FAK (Huang, 2005). Since the expression of MMP-9 and the activation of some kinases involved in cell proliferation and migration closely related to the NF$\kappa \mathrm{B}$ activation, it is suggested that Sirih Merah leaves may potentially to inibit cell migration and metastasis.

*Corresponding author e-mail: ririsjenie@gmail.com 
Previous study showed that Sirih Merah leaves methanolic extract (PCM) inhibited the proliferation of T47D human breast cancer cells (Widowati, et al., 2011) and HeLa cervical cancer cells (Wicaksono, et al., 2009) and exhibited cytotoxic activity in WiDr colon cancer cells (Wulandari, 2015). In this study, we used 4T1 cell culture as the model of metastatic breast cancer cells. This cell line is derived from epithelial tissue of mouse breast gland $\mathrm{BALB} / \mathrm{cfC} 3 \mathrm{H}$. The properties of 4T1 cells are aggressive, highly metastatic, low immunogenic and represent characteristics that resemble stage IV breast cancer in humans (Zwolac, 2008) as well as resistant to 6-thioguanin. 4T1 cells can metastasize in several organs affected by breast cancer including the lungs, liver, brain and bone. In addition, 4T1 breast cancer cells are ER, PR and HER-2/neu negatives thus describing the TNBC phenotype (Mehta, et al., 2013). The aim of this study is to observe the activity of PCM in inhibiting the proliferation and migration of $4 \mathrm{~T} 1$ breast cancer cells.

\section{MATERIALS AND METHODS}

\section{Extract Preparation}

Simplicia of Piper crocatum Ruiz \& Pav leaves were collected from Bina Agro Mandiri Inc., Bantul, Yogyakarta, Indonesia, and determined at Biological Pharmacy Laboratory, UGM. The simplicia were powdered then extracted by soxhlet with $400 \mathrm{~mL}$ methanol on temperature $50^{\circ} \mathrm{C}-70^{\circ} \mathrm{C}$ in 3 cycles of soxhlet. The filtrate was dried using rotary evaporator on $40^{\circ} \mathrm{C}$.

\section{Cell Culture}

4T1 breast cancer cells were obtained from Prof. Masashi Kawaichi (Nara Institute of Science and Technology, NAIST, Japan). The cells were maintained in Dulbecco's Modifies Eagles medium (DMEM) high glucose (Sigma) with 10\% FBS (Sigma), HEPES, sodium bicarbonate, $1500 \mathrm{U} / \mathrm{ml}$ of Penicilin - $1500 \mu \mathrm{g} / \mathrm{mL}$ of Streptomycin and 0.5 $\mu \mathrm{g} / \mathrm{mL}$ Fungizone (Gibco).

\section{Cytotoxic Test}

Cytotoxic test was carried out by MTT assay (Mosmann, 1983). Briefly, 4T1 cells were seeded in 96-well plate with $4 \times 10^{3}$ cells/well and were incubated for 24 hours. After incubation, cells were treated with PCM under increasing concentration of $10,50,75,100,125,250 \mu \mathrm{g} / \mathrm{mL}$ for 24 hours. Media were removed and washed with $100 \mu \mathrm{L}$ PBS (Sigma), MTT reagent was added with the final concentration of $5 \mathrm{mg} / \mathrm{mL}$ to each wells then incubated in $37^{\circ} \mathrm{C}$ for 4 hours. After incubating, stopper reagent SDS $10 \% \mathrm{HCl} 0,01 \mathrm{~N}$ was added and incubating over night. The absorbance was determined with ELISA reader at $\lambda 595 \mathrm{~nm}$ (Biorad).

\section{Scratch Wound Healing Assay}

$4 \mathrm{~T} 1$ cells planted $7.5 \times 10^{4}$ cells/well in $24-$ wellplate. Cells were incubated for 24 hours until $80 \%$ confluen. Media were removed and washed with $100 \mu \mathrm{L}$ PBS (Sigma), media was added with $0.5 \%$ FBS for stravation and incubated for 24 hours. Each well was scratched vertically by using yellow tip and treated with PCM. Then the closures of cell migration were observed in $0,18,24$ and 42 hours under inverted microscope and captured with digital camera.

\section{Data Analysis}

Absorbance data was obtained from cytotoxicity assay then converted to a percent of cell viability. $\mathrm{IC}_{50}$ value calculation is performed by the linear regression method. Scratch analysis was done by measure the migration distance using ImageJ software by comparing the distance between untreated and treated cells.

\section{RESULTS}

\section{Cytotoxic effect of PCM on 4TI cells}

The cytotoxic effects of PCM was conducted by MTT Assay to determine the $\mathrm{IC}_{50}$ value as the parameter, the low $\mathrm{IC}_{50}$ value indicates potential cytotoxicity. $\mathrm{IC}_{50}$ value of PCM is $120 \mu \mathrm{g} / \mathrm{mL}$ on 4T1 cells (Fig. 1). The curved showed that PCM could decrease the cells viability with dose dependent manner.

Based on Prayong, et al. (2008), an $\mathrm{IC}_{50}$ value below $100 \mu \mathrm{g} / \mathrm{mL}$ indicates a potent cytotoxic effect whereas over $100 \mu \mathrm{g} / \mathrm{mL}$ indicates moderate cytotoxicity. Accordingly, PCM has potential $\mathrm{IC}_{50}$ cytotoxic value whereas PCM has $\mathrm{IC}_{50}$ value with moderate cytotoxic category. Even though PCM did not possessed potent cytotoxic effect, it is still interesting to observe the cell migration. 
(a)

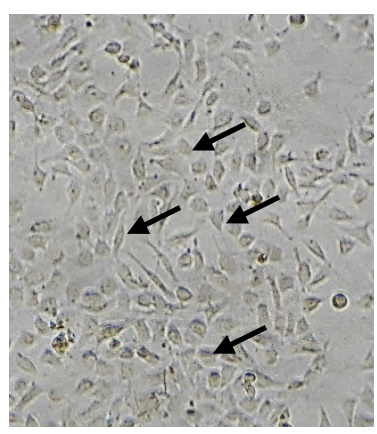

Untreaed cells

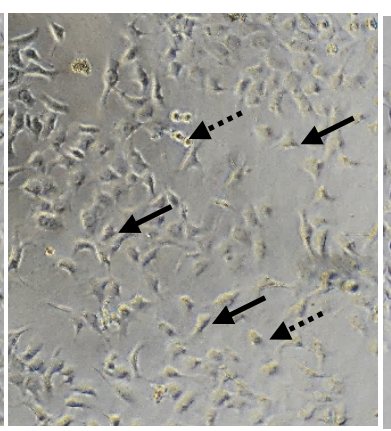

PCM $50 \mu \mathrm{g} / \mathrm{mL}$

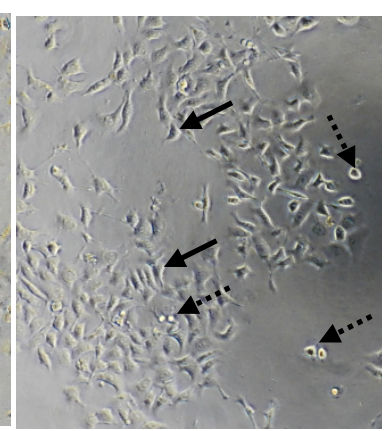

PCM $125 \mu \mathrm{g} / \mathrm{mL}$

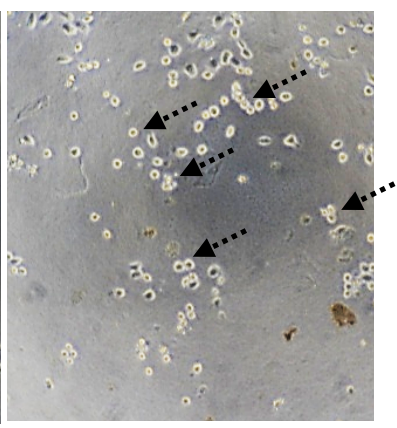

PCM $250 \mu \mathrm{g} / \mathrm{mL}$

(b)

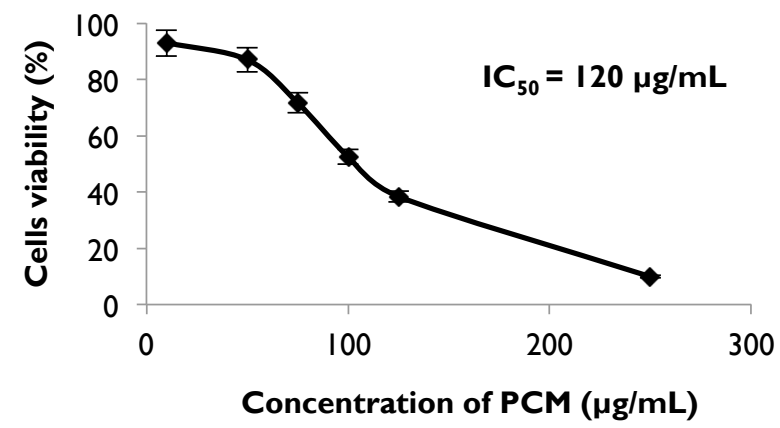

Figure I. Cytotoxic effect of PCM on 4TI cells. 4TI cells $\left(4 \times 10^{3}\right.$ cells/well) were treated with PCM in the concentration as indicated in the figure, then subjected for MTT assay. (a) Morphology of 4TI cells after treatment of PCM. (b) The cell viability profile showed at various concentrations of PCM. The IC 50 value performed triplicate and was calculated by using linear regression in three independent experiments $(p<0.05)$.

\section{Antimigration effect of PCM on 4TI cells}

Cell migration was observed by scratch wound healing assay with various concentration under $\mathrm{IC}_{50}$ value they are $1 / 8,1 / 4$ and $1 / 2$ of $\mathrm{IC}_{50}$ (Fig. 2B). These selected concentrations were considered to not affect the growth of $4 \mathrm{~T} 1$ cells in order that cell migration is able to be observed collectively. The result showed that PCM performed migration inhibitory activity on $4 \mathrm{~T} 1$ cells at the concentration of $30 \mu \mathrm{g} / \mathrm{mL}$ after $18^{\text {th }}$ until $42^{\text {nd }}$ hours scratched. 
(a)
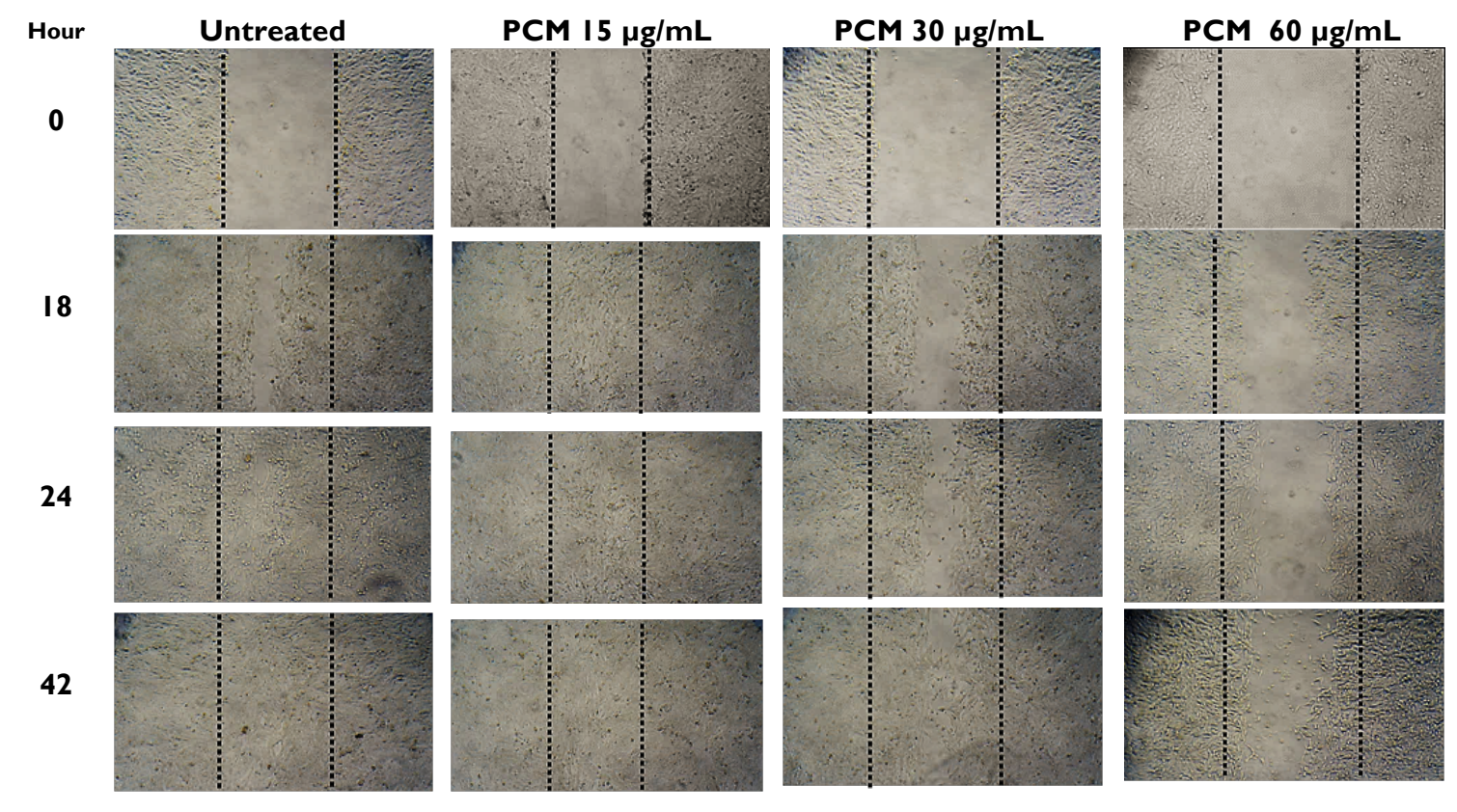

(b)

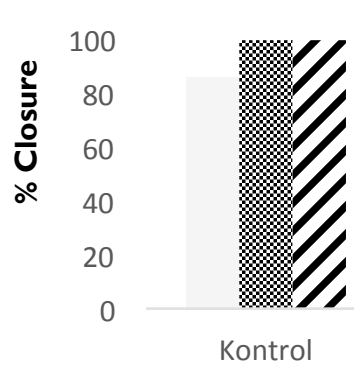

0
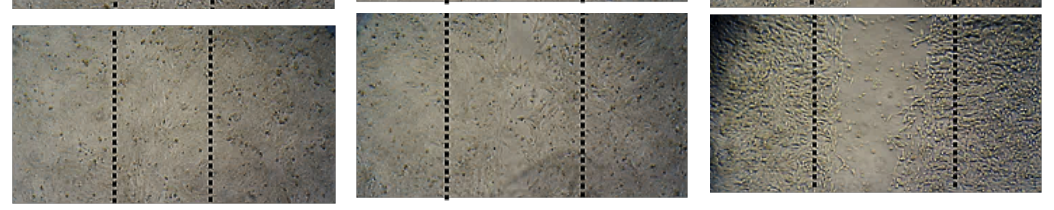

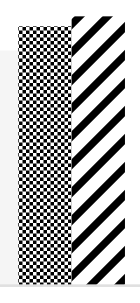

15

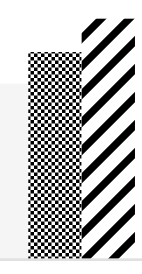

30

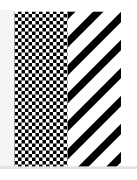

60 $\begin{array}{rr} & \text { Hour }-18 \\ \text { 5. Hour }-42 & \text { Hour }-24\end{array}$

Concentration of SML $(\mu \mathrm{g} / \mathrm{mL})$

Figure 2. Effect of PCM on 4TI Cells Migration. 4TI cells $\left(7.5 \times 10^{4}\right.$ cells/well) were treated with PCM in the concentration as indicated in the figure, then subjected for scratch wound healing assay. (a) The morphology of the cells after scratch and treated with PCM. Observations were made after 18, 24 and 42 hour of treatment under an inverted microscope with magnification of 100x. (b) The percentage of 4TI cells closure after treatment. The area of the scratch were analyzed using Imagej software then \% closure was calculated in accordance with the procedures of the analysis.

\section{DISCUSSION}

Inhibition of tumor cell migration is crucial in the therapeutic and inhibition of cancer spread, especially in metastasis. Thus, it is necessary to develop anti-metastatic agent. The main purpose of this study is to explore the potential metastasisinhibitory of Piper Crocatum Ruiz \& Pav on 4T1 cells. In this study, 4T1 cells were used as the model of human metastatic breast cancer cells (Heppner, et al., 2000).
Previous research has shown that PCM methanolic extract has cytotoxic activity against T47D breast cancer cells through inhibition of p44/p42 phosphorylation associated with cell growth and an important target in cancer therapy (Wicaksono, et al., 2009). Ethanolic extracts of PCM has been also reported to have antiproliferative effects and are able to induce apoptosis in HeLa cervical cancer cells (Wicaksono, et al., 2013).

So far, there have been several studies conducted to determine the inhibitory activity of migration and metastasis of certain compounds in 
some cell types. Some of them are compounds of the class of flavonoids and alkaloids. Flavonoids are a class of low molecular weight polyphenol compounds, which are widely distributed in plants and have activity inhibiting cell migration and endothelial activation (Middleton, et al., 2000). Flavonoid compounds are reported to have activity in inhibition of growth and tumor cell metastasis (Piantelli, 2006). Previously, Huang (2005) reported that flavonoid compounds such as luteolin and quercetin are able to suppress the expression and phosphorylation of FAK and MMP-9 expression in vitro that could trigger invasive potential suppression and cell migration. In addition to flavonoid compounds, certain types of alkaloids are also reported to have metastatic inhibitory activity by inhibiting cell migration, such as piperine. It was reported that piperine is able to inhibit the growth and migration of 4T1 breast cancer cells by inhibiting Erk's phosphorylation in vitro and in vivo (Lai, 2012). Flavonoids are known to be also present in PCM (Manoi, 2007; Hartini, et al., 2013). The presence of the compounds in PCM might be responsible for cytotoxic and migration inhibitory activity.

This study described the potency of PCM as an anti-cancer agent which has the cytotoxic potency of $4 \mathrm{~T} 1$ cell with $\mathrm{IC}_{50}$ values of $120 \mu \mathrm{g} / \mathrm{mL}$ (Fig. 1). The decrease in viability of $4 \mathrm{~T} 1$ breast cancer cells with the phenomenon of dose dependent manner showed that PCM has potential as a chemopreventive agent in breast cancer. However, based on the $\mathrm{IC}_{50}$ value obtained in this study, PCM appeared to have a more potent effect when compared to some extracts that had been tested on 4T1 cells in other previous studies. Some extracts of them are methanolic extract of Prunus africana with $\mathrm{IC}_{50}$ value of $164 \mu \mathrm{g} / \mathrm{mL}$, methanolic extract of Maytenus senegalensis leaves with $\mathrm{IC}_{50}$ value of 256 $\mu \mathrm{g} / \mathrm{mL}$, methanolic extract of Warbugia stuhlmannii with $\mathrm{IC}_{50}$ value of $123 \mu \mathrm{g} / \mathrm{mL}$ (Nabende, 2015) and water extract of Potentilla reptans L. roots with $\mathrm{IC}_{50}$ value of $280 \mu \mathrm{g} / \mathrm{mL}$ (Radovanovic, 2013). This showed that PCM also includes a potent extract against 4T1 cells. Potency of methanolic extract of PCM has also been tested in several cancer cells, among others, on T47D breast cancer cells and colon cancer cells WiDr (Wicaksono et al., 2009; Wulandari et al., 2015). In the studies, methanolic extract of PCM was reported to have cytotoxic activity against human breast cancer cells T47D with $\mathrm{IC}_{50}$ value of $44 \mu \mathrm{g} / \mathrm{mL}$ (Wicaksono, et al., 2009). Meanwhile on WiDr colon cancer cells, it was reported to have cytotoxic activity with $\mathrm{IC}_{50}$ value of $100 \mu \mathrm{g} / \mathrm{mL}$ (Wulandari, 2015). The potential of PCM as a chemopreventive agent may continue to be tested further by fractionation in order to obtain an active fraction that has a greater potential as a chemoprevention agent. Moreover, the cytotoxic activity test in this study has not been able to show the mechanism of cytotoxic activity of PCM in 4T1 cells. The mechanism of death or inhibition of cell proliferation by a compound can occur through the process of apoptosis and or cell cycle arrest. So there is a need for further research to find out what mechanism is responsible for PCM cytotoxic effect on $4 \mathrm{~T} 1$ cells.

In this present study, we also observed the inhibition of cancer cell migration as the one of parts in metastasis process by treatment of PCM through scratch wound healing assay. Based on the percent graph of 4T1 cell closure (Fig. 2B), the treatment of PCM with concentration at $15 \mu \mathrm{g} / \mathrm{mL}$ has not demonstrated any migration inhibitory activity by showing a $\%$ closure profile of the cell similar to cell control's (untreated). In the PCM concentration of $30 \mu \mathrm{g} / \mathrm{mL}, 4 \mathrm{~T} 1$ cells began to show a decrease in percentage closure which indicated that at this concentration, PCM began to effect inhibition of cell migration time dependent from the $18^{\text {th }}$ hour until the $42^{\text {nd }}$ hour. While at $60 \mu \mathrm{g} / \mathrm{mL}$ concentrations of PCM also showed migration inhibitory activity with a smaller \% closure compared to $15 \mu \mathrm{g} / \mathrm{mL}$ and 30 $\mu \mathrm{g} / \mathrm{mL}$. Nevertheless, when viewed on the graph of cell closure (Fig. 2B), the \% closure profile at 60 $\mu \mathrm{g} / \mathrm{mL}$ did not show any increase in time with a $\%$ closure being in the $58 \%$ range. This revealed that at these concentrations PCM is actually capable of inhibiting 4T1 cell migration.

From the results of this study, PCM is shown to have cytotoxic activity and is also able to inhibit the migration of 4T1 breast cancer cells. In this case, inhibition of 4T1 cell migration by PCM is not affected by its cytotoxic activity. Cytotoxic activity and inhibition of cell migration in this study are two things with different mechanisms. This is demonstrated, although with the treatment of PCM at low concentrations under cytotoxic concentrations, PCM is able to inhibit the migration of $4 \mathrm{~T} 1$ breast cancer cells starting at a concentration 
of $30 \mu \mathrm{g} / \mathrm{mL}$. That means, through scratch wound healing test on non-cytotoxic dosing or not killing cells PCM is able to inhibit the closure of $4 \mathrm{~T} 1$ breast cancer-free cell zone starting at a concentration of 30 $\mu \mathrm{g} / \mathrm{mL}$.

The study about methanolic extract of PCM activity in inhibiting cell migration associated with determination of the responsible compound for its activity has never been done before, so there is a need for a continuous series of research in order to infer what mechanisms mediate the inhibition of migrating 4T1 cells by PCM. However, it is possible that the flavonoid compounds contained in PCM are responsible for the inhibitory activity of migrating 4T1 breast cancer cells by inhibiting cell migration in various signaling pathways as described previously. In addition, further studies such as the determination of active compounds on PCM as well as tracing of proteins that play a role in the inhibitory activity of 4T1 cell migration are necessary in order to obtain sufficient and valid interpretation of data to be able to trace the potential of PCM to the metastasis of cancer cells.

\section{CONCLUSION}

PCM has cytotoxic activity on 4T1 metastatic breast cancer cells with $\mathrm{IC}_{50}$ value of $120 \mu \mathrm{g} / \mathrm{mL}$ and exhibit the migration inhibitory activity on the cells at $30 \mu \mathrm{g} / \mathrm{mL}$ concentration $\left(1 / 4\right.$ of $\left.\mathrm{IC}_{50}\right)$.

\section{REFERENCES}

Chang, M.J., Ko, C.Y., Lin, R.F. and Hsieh, L.L., 2002, Biological Monitoring of Environment Exposure to Safrole and the Taiwanese Betel Quid Chewing, Arch. Environ. Contam. Toxicol., 43(4), 432-437.

Eccles, S.A., 2013, Critical Research Gaps and Translational Priorities for the Successful Prevention and Treatment of Breast Cancer, Breast Cancer Res., I 5(5), R92.

Ferreres, F., Oliveira, A.P., Gil-Izquierdo, A., Valentão, P. and Andrade, P.B., 2014, Piper betle Leaves: Profiling Phenolic Compounds by HPLC/DAD-ESI/MSn and Anticholinesterase Activity, Phytochem. Anal., 25(5), 453-460.
Friedl, P., Hegerfeldt, Y. and Tusch, M., 2004, Collective Cell Migration In Morphogenesis and Cancer, Int. J. Dev. Biol., 48(5-6), 44I-449.

Guha, P., 2006, Betel Leaf: The Neglected Green Gold of India, J. Hum. Ecol., I 9(2), 87-93.

Gundala, S.R. and Aneja, R., 2014. Piper betel Leaf: A Reservoir of Potential Xenohormetic Nutraceuticals with Cancer-fighting Properties, Cancer Prev. Res., 7(5), 477-486.

Hartini, Y. S., Wahyuono, S., Widyarini, S. and Yuswanto, A. G., 2013, Aktivitas Fagositosis Makrofag Fraksi dari Ekstrak Metanol Daun Sirih Merah (Piper crocatum Ruiz \& Pav) secara in vitro, J. llmu Kefarmas. Indones., I I, 2.

Heppner, G.H., Miller, F.R. and Shekhar, P.M., 2000, Nontransgenic Models of Breast Cancer. Breast Cancer Res., 2(5), 33 I-334.

Huang, Y.T., Lee, L.T., Lee, H.P., Lin, Y.S. and Lee, M.T., 2005, Targeting of Focal Adhesion Kinase by Flavonoids and Small-interfering RNAs Reduces Tumor Cell Migration Ability, Anticancer Res., 25(3B), 2017-2026.

Lai, L.H., Fu, Q.H., Liu, Y., Jiang, K., Guo, Q.M., Chen, Q.Y., et al., 20I2, Piperine Suppress Tumor Growth and Metastasis in vitro and in vivo in a $4 \mathrm{TI}$ Murine Breast Cancer Model, Acta Pharmacol. Sin., 33(4), 523-530.

Manoi, F., 2007, Sirih Merah sebagai Tanaman Obat Multifungsi, Warta Puslitbangbun, 13, I-2.

Mehta, R.R., Katta, H., Kalra, A., Patel, R., Gupta, A., Alimirah, F., et al., 2013, Efficacy And Mechanism of Action of Deguelin In Suppressing Metastasis of 4TI Cells, Clin Exp. Metastasis, 30(7), 855-866.

Middleton, E., Kandaswami, Jr.C. and Theoharides, T.C., 2000, The Effects of Plant Flavonoids on Mammalian Cells: Implications For Inflammation, Heart Disease and Cancer, Pharmacol. Rev., 52(4), 673-75I.

Mosmann, T., 1983, Rapid Colorimetric Assay for Cellular Growth and Survival: Application to Proliferation and Cytotoxicity Assays, J. Immunol. Methods, 65(I-2), 55-63.

Nabende, P.N., Karanja, S.M., Mwatha, J.K. and Wachira, S.W., 2015, Anti-proliferative Activity of Prunus africana, Warburgia stuhlmannii and Maytenus senegalensis 
Extract in Breast and Colon Cancer Cell Lines, European J. Med. Plants, 5(4), 366-376.

Paranjpe, R., Gundala, S.R., Lakshminarayana, N., Sagwal, A., Asif, G., Pandey, A., et al., 2013, Piper betel Leaf Extract: Anticancer Benefits and Bio-guided Fractionation to Identify Active Principles for Prostate Cancer Management, Carcinogenesis, 34(7), I5581566.

Prayong, P., Barusrux, S. and Weerapreeyakul, N., 2008, Cytotoxic Activity Screening of Some Indigenous Thai Plants, Fitoterapia, 79(7-8), 598-601.

Piantelli, M., Rossi, C., lezzi, M., Sorda, R. L., lacobelli, S., Alberti, S., et al., 2006, Flavonoids Inhibit Melanoma Lung Metastasis by Impairing Tumor Cells Endothelium Interactions, J. Cell. Physiol., 207(I), 23-29.

Radovanovic, A.M., Cupara, S.M., Popovic, S.Lj., Tomovic, M.T., Slavkovska, V.N. and Jankovic, S.M., 2013, Cytotoxic Effect of Potentilla reptans L. Rhixome and Aerial Part Extracts, Acta Pol. Pharm., 70(5), 85I-854.

Sarkar, D., Saha, P., Gamre, S., Bhattacharjee, S., Hariharan, C., Ganguly, S., et al., 2008, Antiinflammatory Effect of Allylpyrocatechol in LPS-induced Macrophages is Mediated by Suppression of iNOS and COX-2 via the NFkappaB Pathway, Int. Immunopharmacol., 8(9), |264-|27|.
Wicaksono, B.D., Handoko, Y.A., Arung, E.T., Kusuma, I.W., Yulia, D., Pancaputra, A.N., et al., 2009, Antiproliferative Effect of the Methanol Extract of Piper crocatum Ruiz \& Pav Leaves on Human Breast (T47D) Cells In-vitro, Trop. J. Pharm. Res., 8(4), 345-352.

Wicaksono, F.M., Desie, S.P.S., Sekti, B.H., Sari, Y., Natalia, E., Lyrawati, D., et al., 2013, PIPERANTHA: Inovasi Terapi Kombinasi Ekstrak Daun Salam (Eugenia polyantha) Dan Sirih Merah (Piper crocatum) Terhadap Peningkatan Aktivitas Fas/Fas-L Pada Regresi Pertumbuhan Kanker Serviks Secara in vitro, Proceeding, PIMNAS DITJEN DIKTI KEMDIKBUD RI, 9 Januari 2015.

Widowati, W., Mozef, T., Risdian, C.,Ratnawati, H., Tjahjani, S., Sandra, F., 20II, The Comparison of Antioxidative and Proliferationlnhibitor Properties of Piper betle L., Catharanthus roseus [L] G.Don, Dendrophtoe petandra L., Curcuma mangga Val. Extracts on T47D Cancer Cell Line, Int. Res. J. Biochem. Bioinform., I (2), 22-28.

Wulandari, N., 2015, Peningkatan Efek Sitotoksik Kombinasi Doxorubicin Dan Ekstrak Metanolik Daun Sirih Merah (Piper crocatum Ruiz \& Pav) pada Sel Kanker Kolon WiDr Melalui Induksi Apoptosis In Vitro, Essay, Fakultas Farmasi Universitas Gadjah Mada, Yogyakarta. 